\title{
Pola Perubahan Dimensi Biji Kopi Arabika (Coffea arabica) Selama Proses Pengeringan
}

\section{(Shrinkage of Arabica Coffee during drying process)}

\author{
Sari Ramadhani ${ }^{1 *)}$, Junaedi Muhidong ${ }^{2)}$ dan Mursalim ${ }^{3)}$ \\ 1) Program Studi Keteknikan Pertanian Universitas Hasanuddin \\ 2) Program Studi Keteknikan Pertanian Universitas Hasanuddin \\ ${ }^{3)}$ Program Studi Keteknikan Pertanian Universitas Hasanuddin \\ *) Email korespondensi: ramadhanisari09@gmail.com
}

\begin{abstract}
ABSTRAK
Kopi arabika (Coffea arabica) merupakan tipe kopi tradisional dengan cita rasa terbaik. Biji kopi yang dihasilkan berwarna hijau hingga merah gelap. Kopi ini berasal dari Etiopia dan sekarang telah dibudidayakan di berbagai belahan dunia, mulai dari Amerika Latin, Afrika Tengah, Afrika Timur, India dan Indonesia. Secara umum, kopi ini dapat tumbuh di daerah dengan ketinggian 700-1.700 m dpl, suhu tumbuh optimalnya adalah 16-200C. Tujuan dari penelitian ini adalah untuk mengetahui perubahan dimensi biji kopi selama proses pengeringan akibat adanya perubahan kadar air untuk dijadikan sebagai bahan informasi bagi petani kopi dan industri pengolahan biji kopi serta desain mesin pascapanen kopi. Penelitian ini menggunakan biji kopi yang diperoleh dari desa Kalimbua, kecamatan Baroko, kabupaten Enrekang. Parameter yang diamati adalah perubahan panjang, lebar dan tebal yang digunakan untuk menghitung diameter geometri, berat biji kopi dan kadar air. Pengeringan dilakukan dengan menggunakan alat pengering tray dryer dengan variasi suhu (500C dan 600C) dan kecepatan udara 1,0 m/s. Pengukuran dimensi dan berat dilakukan pada 0 jam sampai dengan 12 jam. Penelitian menunjukkan bahwa terjadi penurunan dimensi (panjang, lebar dan tebal) biji kopi arabika sejalan dengan bertambahnya waktu pengeringan dan penurunan kadar air bahan. Pola penurunan dimensi ini seiring dengan lama pengeringan dan perubahan kadar air mengikuti pola logarithmic dengan nilai R2 lebih besar dari 0,90. Pola penurunan diameter geometri pada saat kadar air basis kering menurun mengikuti pola logarithmic.
\end{abstract}

Kata Kunci: Kopi arabika, pengeringan, dimensi.

\section{PENDAHULUAN}

\section{Latar Belakang}

Kopi merupakan salah satu minuman paling populer di dunia yang dikonsumsi oleh berbagai kalangan masyarakat. Kopi juga merupakan salah satu komoditas andalan perkebunan penghasil devisa ekspor, sumber pendapatan petani, penghasil bahan baku industri, serta penciptaan lapangan kerja dan pengembangan wilayah. Produktivitas kopi di Indonesia cukup tinggi sebesar $792 \mathrm{~kg}$ biji kering per hektar per tahun, membuat Indonesia menduduki posisi keempat di dunia dalam hal produksinya.

Kadar air awal kopi putih sekitar 50$55 \%$ sehingga memberikan peluang yang besar untuk cepat membusuk akibat adanya pertumbuhan mikroorganisme. Oleh karena itu, pengeringan dapat mengurangi kadar air dalam biji. 
Berdasarkan uraian di atas, maka perlu dilakukan penelitian untuk mengetahui hubungan kadar air terhadap perubahan dimensi biji kopi selama proses pengeringan.

\section{Tujuan dan Kegunaan}

Tujuan penelitian ini adalah untuk mengetahui perubahan dimensi biji kopi selama proses pengeringan akibat adanya perubahan kadar air.

Kegunaan penelitian ini adalah untuk dijadikan bahan informasi bagi petani kopi dan industri pengolahan biji kopi serta desain mesin pascapanen kopi.

\section{METODOLOGI PENELITIAN}

\section{Alat dan Bahan}

Alat yang digunakan dalam penelitian ini adalah timbangan digital, oven, tray dryer model EH-TD-300 Eunha Fluid Science dan jangka sorong.

Bahan yang digunakan adalah kopi arabika yang dipanen sebanyak $4 \mathrm{~kg}$ yang diperoleh dari desa Kalimbua, kecamatan Baroko, kabupaten Enrekang.

\section{Parameter Penelitian}

Parameter perlakuan dalam penelitian ini mencakup dua level perubahan suhu alat pengering yaitu $50 \mathrm{oC}$ dan 60oC. Sedangkan parameter pengamatan dalam penelitian ini antara lain:

a. Dimensi biji kopi (panjang, lebar, tebal). Dimensi ini digunakan untuk menghitung diameter geometri mengikuti formula berikut ini.

$$
D=\sqrt[3]{p \cdot l . t}
$$

Keterangan:

$\mathrm{D}=$ Diameter geometri $(\mathrm{mm})$

$\mathrm{p}=$ Panjang $(\mathrm{mm})$

$1=\operatorname{Lebar}(\mathrm{mm})$

$\mathrm{t}=$ Tebal $(\mathrm{mm})$

b. Berat biji kopi

c. Kadar Air meliputi kadar air basis kering (KAbk, \%). Kadar air ditentukan dengan menghitung berat bahan dan berat air yang menguap selama pengeringan.

$$
m=\frac{A-B}{B} \times 100 \%
$$

Keterangan:

$\mathrm{m}=$ kadar air basis kering $(\%)$

$\mathrm{A}=$ berat awal $(\mathrm{g})$

$\mathrm{B}=$ berat akhir $(\mathrm{g})$

\section{Bagan Alir}

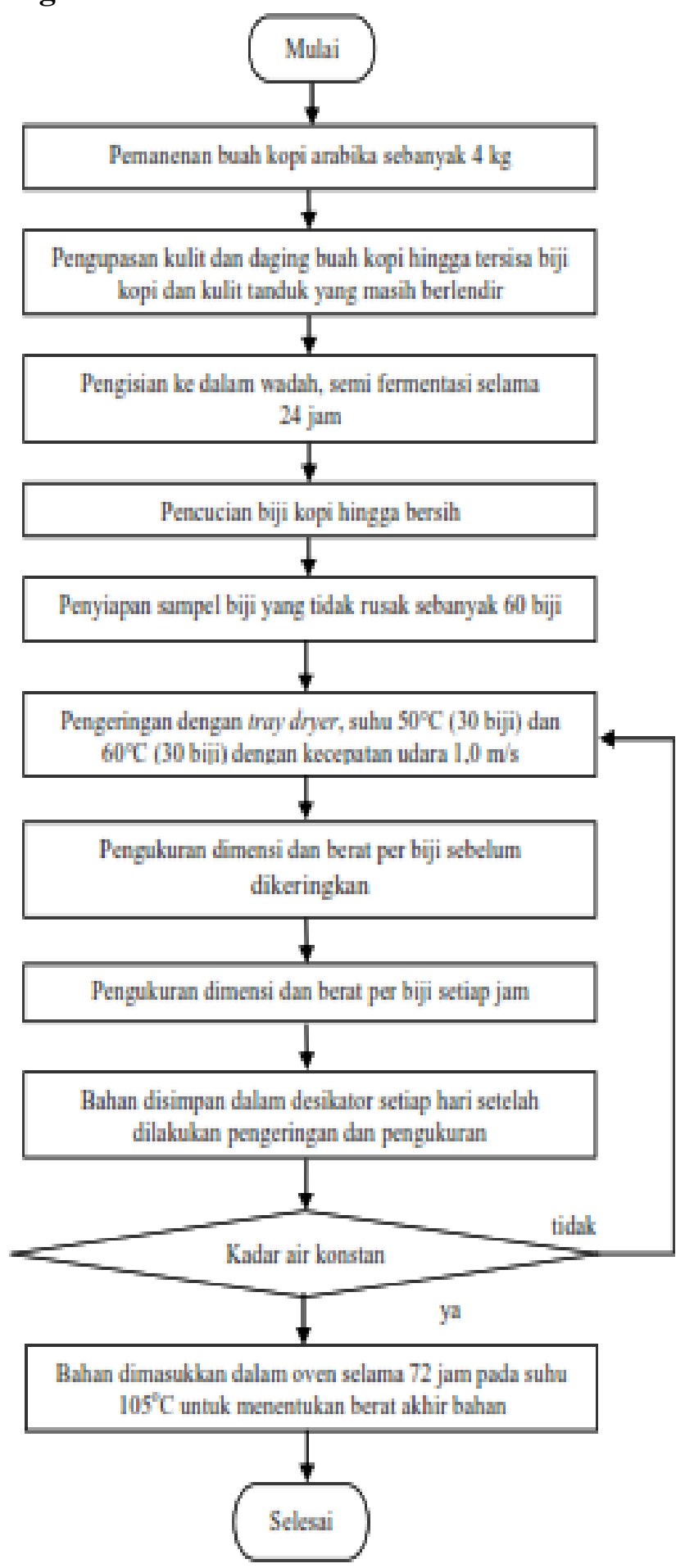

Gambar 1. Bagan Alir Penelitian 


\section{HASIL DAN PEMBAHASAN}

\section{Berat dan Kadar Air}

Hasil pengamatan terhadap berat biji kopi arabika dan kadar air yang diperoleh pada suhu 500C dan 600C disajikan pada Tabel 1 dan 2 berikut:

Tabel 1. Rata-rata berat dan kadar air per biji kopi arabika pada suhu $50^{\circ} \mathrm{C}$ berdasarkan lama pengeringan

\begin{tabular}{ccc}
\hline $\begin{array}{c}\text { Lama } \\
\text { pengeringan } \\
\text { (jam) }\end{array}$ & $\begin{array}{c}\text { Berat biji } \\
\text { kopi }(\mathbf{g})\end{array}$ & $\begin{array}{c}\text { KA BK } \\
(\%)\end{array}$ \\
\hline 0 & 0.461 & 90 \\
1 & 0.427 & 76 \\
2 & 0.398 & 64 \\
3 & 0.383 & 58 \\
4 & 0.364 & 50 \\
5 & 0.341 & 41 \\
6 & 0.325 & 34 \\
7 & 0.308 & 27 \\
8 & 0.301 & 24 \\
9 & 0.290 & 20 \\
10 & 0.283 & 17 \\
11 & 0.276 & 14 \\
12 & 0.275 & 14 \\
\hline
\end{tabular}

Tabel 2. Rata-rata berat dan kadar air per biji kopi arabika pada suhu $60^{\circ} \mathrm{C}$ berdasarkan lama pengeringan

\begin{tabular}{ccc}
\hline $\begin{array}{c}\text { Lama } \\
\text { pengeringan } \\
\text { (jam) }\end{array}$ & $\begin{array}{c}\text { Berat biji kopi } \\
(\mathbf{g})\end{array}$ & $\begin{array}{c}\text { KA K } \\
(\%)\end{array}$ \\
\hline 0 & 0.472 & 85 \\
1 & 0.429 & 68 \\
2 & 0.387 & 52 \\
3 & 0.354 & 39 \\
4 & 0.328 & 28 \\
5 & 0.313 & 23 \\
6 & 0.291 & 14 \\
7 & 0.286 & 12 \\
8 & 0.279 & 9 \\
9 & 0.268 & 5 \\
10 & 0.278 & 8 \\
11 & 0.274 & 7 \\
12 & 0.271 & 6 \\
\hline Catatan: Pengeringan setelah jam ke-9 dihentikan \\
selama sekitar 3 hari karena cuaca sedang hujan \\
deras yang dikhawatirkan akan mengganggu laju \\
pengeringan. Namun demikian, biji kopi nampaknya \\
tetap menyerap uap air selama penyimpanan di \\
dalam desikator & sehingga berat sampel pada \\
pengukuran jam ke-10 meningkat. &
\end{tabular}

Tabel 1 dan 2 di atas menunjukkan penurunan berat dan kadar air biji kopi arabika padamasing-masing pengeringan suhu $50^{\circ} \mathrm{C}$ dan suhu $60^{\circ} \mathrm{C}$ seiring dengan lama waktu pengeringan. Perubahan berat biji dipengaruhi oleh lama pengeringan yaitu semakin lama pengeringan maka semakin kecil berat biji kopi. Penurunan berat pada suhu $50^{\circ} \mathrm{C}$ dapat dilihat pada berat awal biji kopi arabika adalah 0.461 gram pada waktu pengeringan 0 jam dan berat akhirnya 0.275 gram pada waktu pengeringan 12 jam. Perubahan kadar air biji kopi dipengaruhi lama pengeringan yaitu semakin lama pengeringan maka semakin kecil kadar air biji kopi. Kadar air basis kering awal biji kopi pada suhu 500C adalah $90 \%$ dan kadar air basis kering akhirnya sebesar 14\%. Sedangkan untuk pengeringan dengan suhu $60^{\circ} \mathrm{C}$, penurunan berat tersebut dapat dilihat pada berat awal biji kopi sebesar 0.472 gram dengan kadar air basis kering awal adalah $85 \%$ dan berat akhirnya 0.271 gram dengan kadar air basis kering akhirnya sebesar $6 \%$ basis kering

\section{Hubungan Berat, Lama pengeringan dan Kadar Air}

Hasil pengamatan terhadap berat biji kopi arabika, lama pengeringan dan kadar air yang diperoleh selama pengeringan disajikan pada Gambar 3 dan 4 berikut:

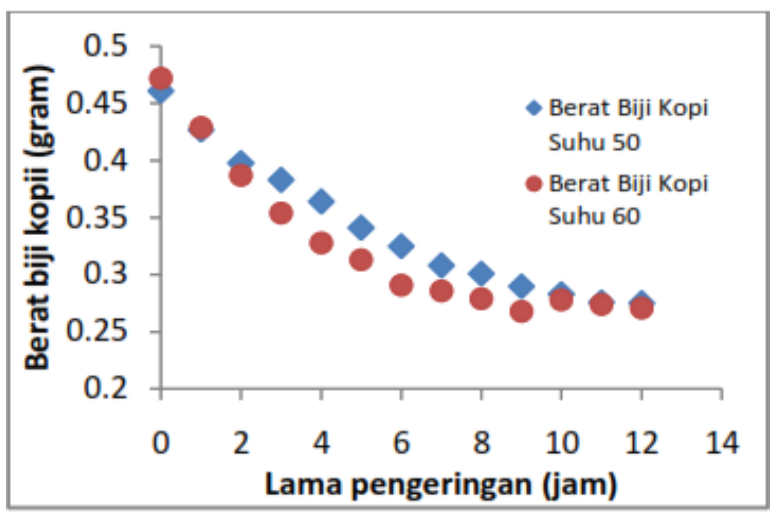

Gambar 3. Grafik hubungan antara berat biji kopi arabika dengan lama pengeringan 


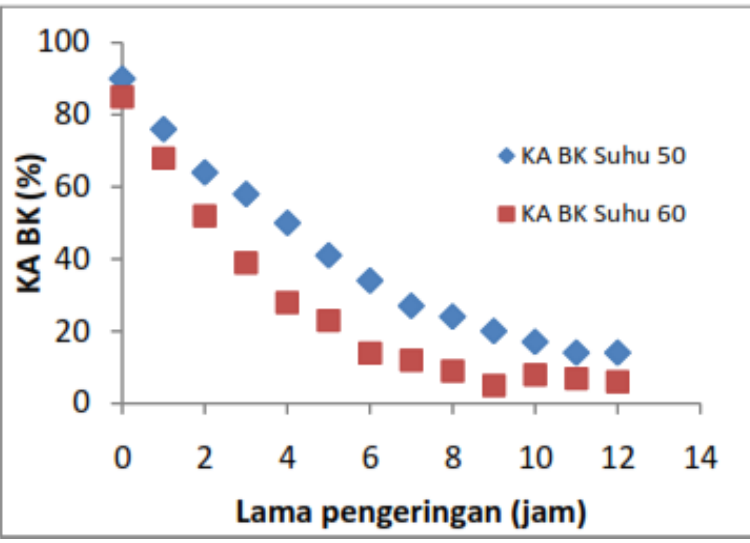

Gambar 4. Grafik hubungan antara kadar air basis kering biji kopi arabika dengan lama pengeringan

Gambar 3 menunjukkan grafik hubungan antara berat biji kopi arabika dengan lama pengeringan. Dari hasil pengamatan yang telah dilakukan, berat biji kopi selama proses pengeringan mengalami penurunan. Perubahan berat biji dipengaruhi oleh lama pengeringan yaitu semakin lama pengeringan maka semakin kecil berat biji kopi. Penurunan berat dapat dilihat pada rata-rata berat awal biji kopi sebesar $0.467 \mathrm{~g}$ pada saat 0 jam dan rata-rata berat akhirnya sebesar 0.273 gram pada saat 12 jam.

Dari Gambar 4 dapat dilihat grafik hubungan antara kadar air basis kering biji kopi arabika dengan lama pengeringan. Kadar air basis kering selama proses pengeringan mengalami penurunan. Perubahan kadar air biji kopi dipengaruhi oleh lama pengeringan yaitu semakin lama pengeringan maka semakin kecil kadar air biji kopi. Penurunan kadar air biji kopi dapat dilihat pada rata-rata kadar air basis kering awal biji kopi sebesar $88 \%$ dan ratarata kadar air basis kering akhirnya sebesar $10 \%$.

\section{Hubungan Panjang, Lama pengeringan dan Kadar Air}

Hasil pengamatan terhadap panjang biji kopi arabika, lama pengeringan dan kadar air yang diperoleh selama pengeringan disajikan pada Gambar 5 dan 6 berikut:

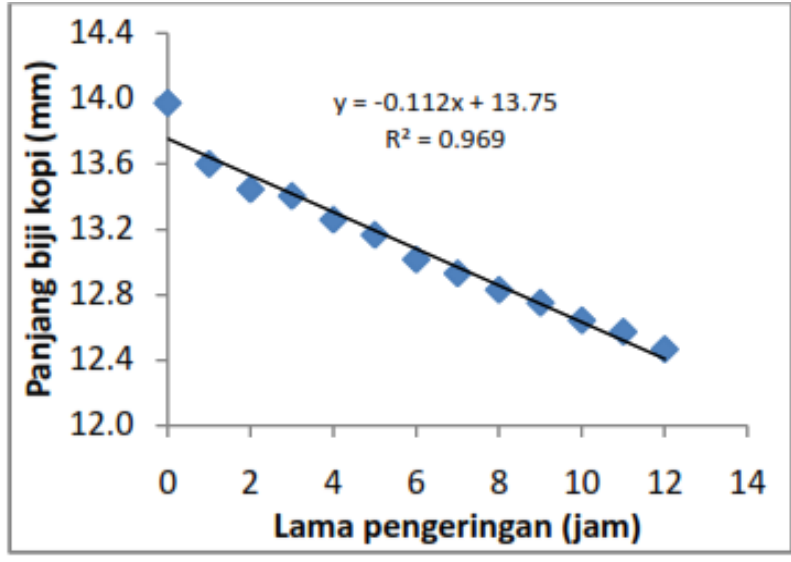

Gambar 5. Grafik hubungan antara panjang biji kopi arabika dengan lama pengeringan



Gambar 6. Grafik hubungan antara panjang biji kopi arabika dengan kadar air basis kering

Dari Gambar 5 di atas menunjukkan grafik hubungan antara panjang biji kopi arabika dengan lama pengeringan. Dari hasil pengamatan yang telah dilakukan, panjang biji kopi selama proses pengeringan juga mengalami penurunan. Perubahan panjang dipengaruhi oleh lama pengeringan yaitu semakin lama pengeringan maka semakin kecil panjang biji kopi, mengikuti pola logarithmic Penurunan panjang dapat dilihat pada ratarata panjang awal biji kopi sebesar 13.98 $\mathrm{mm}$ pada saat 0 jam dan rata-rata panjang akhirnya sebesar $12.47 \mathrm{~mm}$ pada saat 12 jam.

Gambar 6 dapat dilihat grafik hubungan antara panjang biji kopi arabika dengan kadar air basis kering (KAbk). Perubahan kadar air dipengaruhi oleh 
panjang biji kopi yaitu semakin tinggi kadar air maka semakin besar pula panjang biji. Hal ini terlihat pada rata-rata panjang awal biji kopi sebesar $13.98 \mathrm{~mm}$ dengan rata-rata kadar air basis kering awal sebesar $88 \%$, untuk rata-rata panjang akhir diperoleh nilai sebesar $12.47 \mathrm{~mm}$ dengan rata-rata kadar air basis kering akhirnya sebesar $10 \%$. Hal ini disebabkan karena selama proses pengeringan kadar air dalam bahan mengalami penguapan sehingga bahan menyusut menyebabkan panjang biji kopi mengalami penurunan seiring dengan penurunan kadar air bahan.

\section{Hubungan Lebar, Lama pengeringan dan Kadar Air}

Hasil pengamatan terhadap lebar biji kopi arabika, lama pengeringan dan kadar air yang diperoleh selama pengeringan disajikan pada Gambar 7 dan 8 berikut:

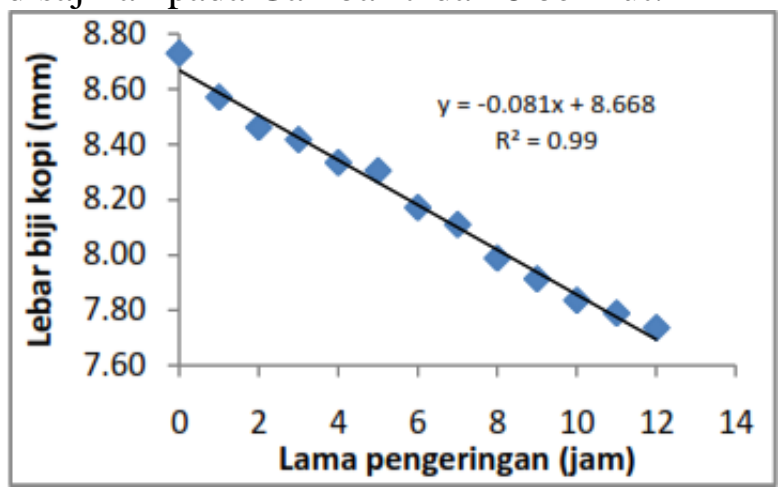

Gambar 7. Grafik hubungan antara lebar biji kopi arabika dengan lama pengeringan

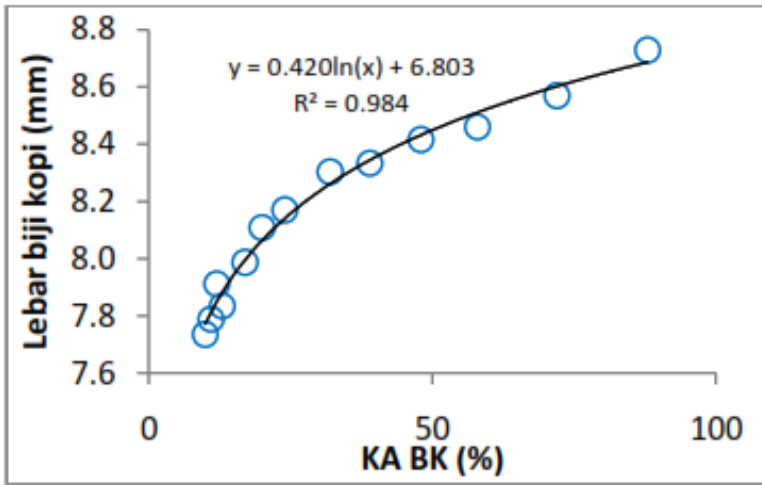

Gambar 8. Grafik hubungan antara lebar biji kopi arabika dengan kadar air basis kering
Gambar 7 di atas menunjukkan grafik hubungan antara lebar biji kopi arabika dengan lama pengeringan. Lebar biji kopi selama proses pengeringan juga mengalami penurunan. Perubahan lebar dipengaruhi oleh lama pengeringan yaitu semakin lama pengeringan maka semakin kecil lebar biji kopi, mengikuti pola logarithmic. Penurunan lebar dapat dilihat pada rata-rata lebar awal biji kopi sebesar $8.73 \mathrm{~mm}$ pada saat 0 jam dan rata-rata lebar akhirnya sebesar $7.74 \mathrm{~mm}$ pada saat 12 jam.

Pada Gambar 8 menunjukkan grafik hubungan antara kadar air dan lebar biji kopi arabika. Kadar air dan lebar biji kopi saling berkaitan. Semakin tinggi nilai kadar air maka semakin besar pula lebar biji. Hal ini terlihat pada rata-rata lebar awal biji kopi sebesar $8.73 \mathrm{~mm}$ dengan rata-rata kadar air basis kering awal sebesar $88 \%$, untuk rata-rata lebar akhirnya diperoleh nilai sebesar $7.74 \mathrm{~mm}$ dengan rata-rata kadar air basis kering akhirnya sebesar $10 \%$. Hal ini disebabkan karena selama proses pengeringan kadar air dalam bahan mengalami penguapan sehingga bahan menyusut menyebabkan lebar biji kopi mengalami penurunan seiring dengan penurunan kadar air bahan.

Hubungan Tebal, Lama pengeringan dan Kadar Air

Hasil pengamatan terhadap tebal biji kopi arabika, lama pengeringan dan kadar air yang diperoleh selama pengeringan disajikan pada Gambar 9 dan 10 berikut:

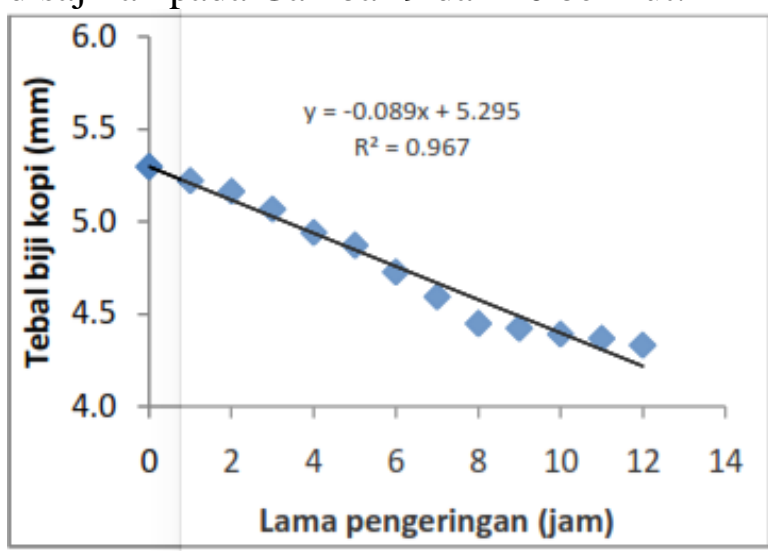

Gambar 9. Grafik hubungan antara tebal biji kopi arabika dengan lama pengeringan. 


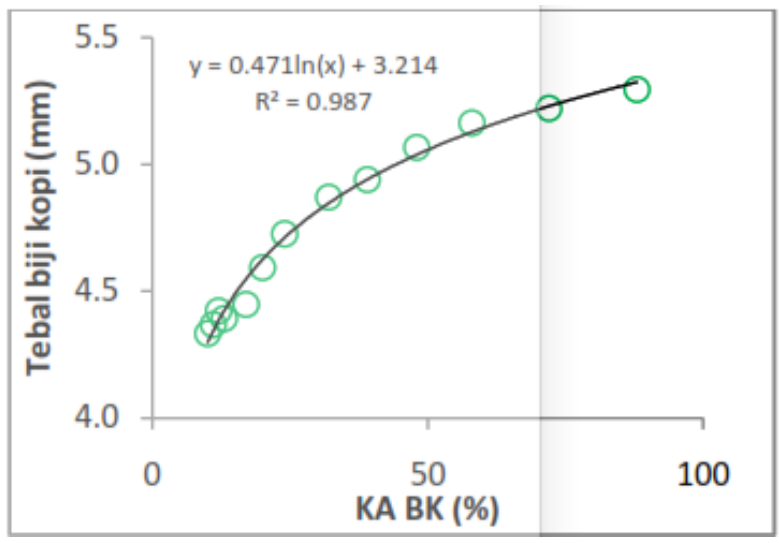

Gambar 10. Grafik hubungan antara tebal biji kopi arabika dengan kadar air basis kering

Gambar 9 di atas menunjukkan grafik hubungan antara tebal biji kopi dengan lama pengeringan. Tebal biji kopi selama proses pengeringan mengalami penurunan. Perubahan tebal dipengaruhi oleh lama pengeringan yaitu semakin lama pengeringan maka semakin kecil tebal biji kopi, mengikuti pola logarithmic. Penurunan tebal dapat dilihat pada rata-rata tebal awal biji kopi sebesar $5.30 \mathrm{~mm}$ pada saat 0 jam dan rata-rata tebal akhirnya sebesar $4.33 \mathrm{~mm}$ pada saat 12 jam.

Dari Gambar 10 menunjukkan pengaruh kadar air terhadap perubahan tebal biji kopi arabika. Semakin tinggi nilai kadar air maka semakin besar pula tebal biji kopi. Hal ini terlihat jelas pada rata-rata tebal awal biji kopi sebesar $5.30 \mathrm{~mm}$ dengan rata-rata kadar air basis kering awal sebesar $88 \%$, untuk rata-rata tebal akhirnya diperoleh nilai sebesar $4.33 \mathrm{~mm}$ dengan rata-rata kadar air basis kering akhirnya sebesar $10 \%$.

\section{Hubungan Diameter Geometri dengan Kadar Air}

Hasil pengamatan terhadap diameter geometri biji kopi arabika dengan kadar air yang diperoleh selama pengeringan disajikan pada Gambar 11 berikut:

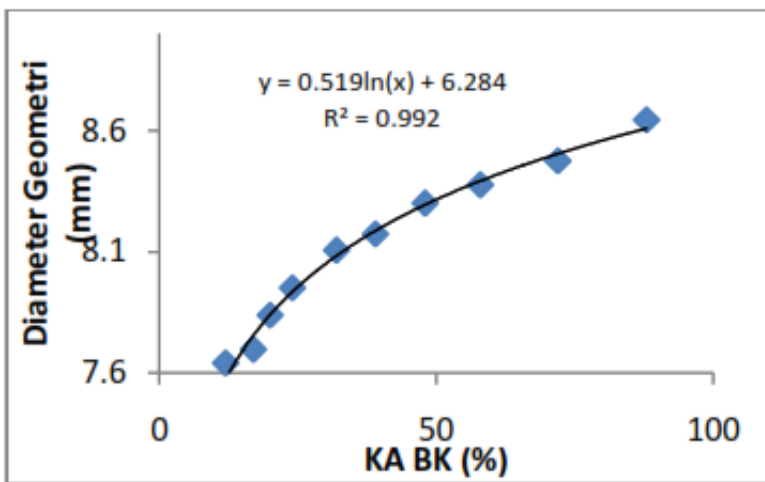

Gambar 11. Grafik hubungan antara diameter geometri dengan kadar air basis kering

Gambar 11 menunjukkan bahwa grafik hubungan antara diameter geometri dengan kadar air basis kering mengikuti pola logarithmic dengan nilai R2 sebesar 0.992. Rata-rata diameter geometri awal biji kopi sebesar $8.64 \mathrm{~mm}$ pada saat ratarata kadar air basis kering awal sebesar $88 \%$, sedangkan rata-rata diameter geometri akhirnya diperoleh sebesar 7.48 $\mathrm{mm}$ pada saat rata-rata kadar air basis kering mencapai sekitar $10 \%$.

\section{KESIMPULAN}

Kesimpulan penelitian ini adalah:

1. Terjadi penurunan dimensi (panjang, lebar, tebal) biji kopi arabika sejalan dengan bertambahnya waktu pengeringan dan penurunan kadar air bahan.

2. Pola penurunan dimensi ini seiring dengan lama pengeringan dan perubahan kadar air mengikuti pola logarithmic dengan nilai R2 lebih besar dari

3. Pola penurunan diameter geometri pada saat kadar air basis kering menurun mengikuti pola logarithmic.

\section{DAFTAR PUSTAKA}

Anggara, Anies. 2011. Kopi Si Hitam Menguntungkan, Budidaya Dan Pemasaran. Cahaya Atma Pustaka. Yogyakarta. 
Ciptadi, W. dan Nasution, M.Z. 1985. Pengolahan Kopi. Fakultas Teknologi Institut Pertanian Bogor.

Clarke, R.J. and Macrae, R. 1987. Coffe chemistry. Elsevier Applied Science, London and New York.

Estiasih, Teti dan Kgs Ahmadi. 2009. Teknologi Pengolahan Pangan. Bumi Aksara. Malang.

Harrys, P. M. J. 2010. Uji Lama Pengeringan dan Tebal Tumpukan Pada Pengeringan Ubi Jalar dengan Alat Pengering Surya Tipe Rak. Departemen Teknologi Pertanian. Fakultas Pertanian, Universitas Sumatera Utara.

Mahadi. 2007. Model Sistem dan Analisa Pengering Produk Makanan. USU Repository. Universitas Sumatera Utara.

Mumin MA, Akhter KF, Abedin MZ and Hossain MZ. 2006. Determination and characterizationof caffeine in tea coffee and soft drink bysolid phase extraction and HPLC, Malaysian J. Chem.

Safrizal, R. 2010. Kadar Air Bahan. Teknik Pasca Panen. Jurusan Teknik Pertanian, Fakultas Pertanian, Universitas Syiah Kuala.

Taib, G., Said, G., dan Wiraatmadja, S. 1988. Operasi Pengeringan Pada Pengolahan Hasil Pertanian. PT Mediyatama Sarana Perkasa. Jakarta.

Yahmadi, Mudrig. 2007. Rangkaian Perkembangan dan Permasalahan Budidaya \& Pengolahan Kopi di Indonesia. 